\title{
Scaling up advocacy for gender-based violence and child sexual abuse in the East, Central and Southern Africa region: Technical exchange and meeting
}

East Central and Southern African Health Community

Follow this and additional works at: https://knowledgecommons.popcouncil.org/departments_sbsr-rh

Part of the Demography, Population, and Ecology Commons, Domestic and Intimate Partner Violence Commons, Family, Life Course, and Society Commons, Health Policy Commons, International Public Health Commons, Maternal and Child Health Commons, and the Women's Health Commons How does access to this work benefit you? Let us know!

\section{Recommended Citation}

"Scaling up advocacy for gender-based violence and child sexual abuse in the East, Central and Southern Africa region: Technical exchange and meeting," Report of a meeting at Ngurdoto Mountain Lodge Hotel, Arusha, Tanzania, December 2012. 


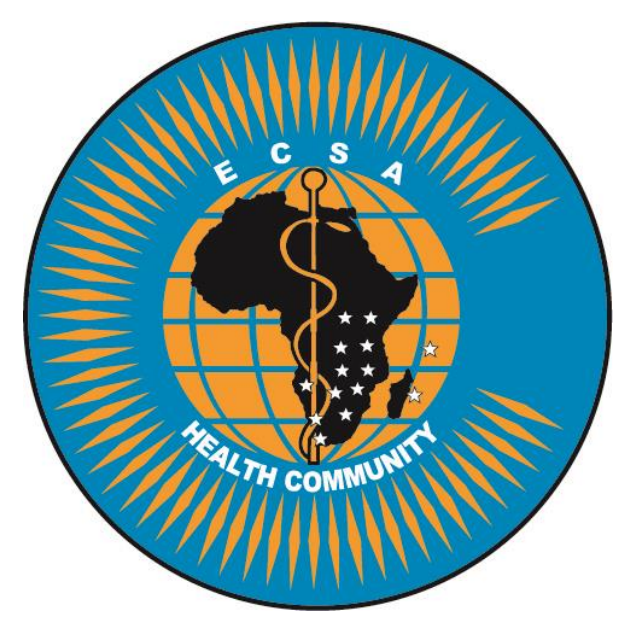

The East, Central and Southern Africa Health Community

\section{SCALING UP ADVOCACY FOR GENDER-BASED VIOLENCE AND CHILd SEXUAL ABUSE IN THE EAST, CENTRAL AND SOUTHERn AfRICA REGION}




\section{Scaling Up Advocacy for Gender-Based Violence and Child Sexual Abuse in the East, Central and Southern Africa Region}

The East, Central and Southern Africa Health Community

September 2013 


\section{Foreword}

The East, Central and Southern Africa Health Community (ECSA Health Community) continues to prioritize gender-based violence (GBV) and child sexual abuse (CSA), as regional health concerns, recognizing them as key hindrances to the full enjoyment of health and other rights, especially for women and children.

We are committed to strengthening the internal capacity of the ECSA Health Community Secretariat, as well as that of ECSA Health Community Member States, to effectively plan for, implement and evaluate evidence-based GBV and CSA interventions that are cost-effective and sustainable. These interventions must be comprehensive in design and multi-sectoral in response, taking into account the mutually-reinforcing connectivity between health, justice and social support systems. In this regard, we are guided by Resolution 4 of the $52^{\text {nd }}$ Conference of Health Ministers (ECSA/HMC52/R42010), which urged Member States to 1) adopt/adapt the ECSA Health Community Regional Prototype Policy on GBV and CSA, and 2) establish or strengthen a national Gender Commission to oversee GBV- and CSA-related interventions, including coordination, advocacy, and establishment of monitoring and evaluation systems.

It is for this reason that ECSA Health Community partnered with the Population Council to convene a pre-conference Expert Committee meeting of the Research, Information and Advocacy (RIA) Programme in December 2012, with funding from the Swedish-Norwegian Regional HIV \& AIDS Team for Africa. The meeting, entitled 'Scaling Up Advocacy for GBV and CSA in the ECSA Region,' drew from the expertise of over thirty participants, including Gender Focal Points and Public Relations Officers from Ministries of Health, journalists, and development partners from Kenya, Lesotho, Malawi, Mauritius, Tanzania, Uganda, Zambia, and Zimbabwe. The meeting culminated in the development of a regional and country-specific plans and actions for advocacy in GBV and CSA. The outcomes of the meeting were formally approved by the $56^{\text {th }}$ Conference of Health Ministers, including the formal establishment of the Research, Information and Advocacy (RIA) Programme's Expert Committee as part of the governance structure of ECSA Health Community. This has provided us with further momentum to tackle the challenges of GBV and CSA both at the country and regional levels. We urge Member States to keep this momentum alive through active advocacy around GBV and CSA.

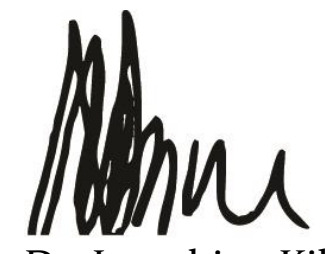

Dr. Josephine Kibaru-Mbae

Director General, East Central and Southern African Health Community 


\section{Preface}

The formal launching of ECSA Health Community's Research, Information and Advocacy (RIA) Expert Committee at the $56^{\text {th }}$ ECSA Health Ministers Conference marks a major milestone in ECSA Health Community's commitment to promote and support region-wide sharing and utilization of health research and policy information among its Member States. It is gratifying to note that the first order of business for the RIA programme was the convening of a pre-conference workshop to scale up advocacy for gender-based violence (GBV) and child sexual abuse (CSA) in the ECSA Region, with participation of officials from key government ministries, media practitioners and development partners from six member states, and with technical support from the Population Council.

The workshop explored key obstacles to effective GBV and CSA prevention and response across ECSA member states and the ways in which these can be more effectively addressed. Notable barriers identified include poor resource allocation and a general lack of technical capacity and political commitment in translating international, regional and national instruments on GBV and CSA into implementable national programmes. Systematic bottlenecks such as poor coordination, collaboration and cooperation between and among government and civil society as well as the absence of a monitoring and evaluation framework were cited as hindering progress towards reducing cases of GBV and CSA.

More importantly, participants shared information and experiences on interventions that work, culminating in the development of country-specific action plans by participating Member States. Adequate resource allocation, media and community participation, as well as improved coordination and cross-sectoral linkages were among some of the interventions identified as critical in the fight against GBV and CSA in the region.

This report summarizes the deliberations of the two-day workshop and the recommendations for implementing an advocacy plan to address this important facet of our development agenda.

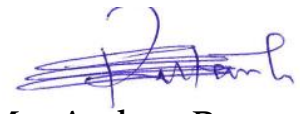

Mr. Arthur Rutaroh

Manager,

Research, Information \& Advocacy
Dr. Odongo Odiyo

Manager

Family and Reproductive Health 


\section{Acknowledgements}

The East, Central and Southern Africa Health Community acknowledges with thanks the valuable contributions and support of Member States and our partners. The meeting upon which this report is based was made possible with funding from the Swedish-Norwegian Regional HIV and AIDS Team for Africa, through the Population Council's Nairobi Office. 


\section{Executive Summary}

From December 11-12, 2012, the Research, Information and Advocacy (RIA) Programme of the East, Central and Southern Africa Health Community (ECSA Health Community) convened its first Expert Committee meeting, entitled 'Scaling Up Advocacy for GBV and CSA in the ECSA Region.' This meeting was organized as a preconference event, leading up to the $56^{\text {th }}$ ECSA Health Ministers Conference which took place from December 13-14, 2012. The pre-conference meeting of ECSA Health Community's RIA programme was attended by over thirty participants, representing Gender Focal Points and Public Relations Officers (both drawn from Ministries of Health), journalists, and development partners from the following ECSA Health Community Member States: Kenya, Lesotho, Malawi, Mauritius, Tanzania, Uganda, Zambia, and Zimbabwe.

The objectives of the meeting were to: 1) share emerging lessons from the region on 'doable' gender-based violence (GBV) and child sexual abuse (CSA) interventions and advocacy activities, drawing on the regional work of ECSA Health Community and the Population Council; 2) identify and prioritize regional advocacy concerns around GBV and CSA; and 3) draw country-specific advocacy plans to feed into a comprehensive, regional plan for GBV.

This report details the proceedings of the meeting, highlighting the key issues identified by participants and the main themes that emerged from plenary discussions on 'Scaling Up Advocacy for GBV and CSA in the ECSA Region,' including the following:

- As GBV is a key determinant of health, associations between GBV and other health issues/disease burdens need to be clarified, emphasized and programmatically addressed.

- Inter-ministerial coordination in national GBV responses requires strengthening.

- Knowledge about the status of child sexual abuse is still sparse in the region.

- In-service training for providers should incorporate a specific focus on GBV.

- Similar priorities areas for GBV advocacy were identified by individual Member States (namely, advocacy for: resource allocation/mobilization; addressing negative social norms; media engagement; and capacity-building of providers).

- Despite the limitations that exist in many countries, multi-sectoral GBV interventions are doable.

- The Expert Committee of ECSA Health Community's Research, Information and Advocacy Programme was formally established during this meeting.

Participants left the meeting with a deep appreciation of the need for a multi-sectoral response to GBV and CSA and with a commitment toward prioritizing advocacy in GBV among Member States. Draft national work plans on GBV were developed to guide these advocacy efforts and ECSA Health Community's newest Expert Committee on Research, Information and Advocacy was later ratified by the $56^{\text {th }}$ Health Ministers Conference, formally establishing the RIA Expert Committee as the fifth such committee of ECSA Health Community. 


\section{Contents}

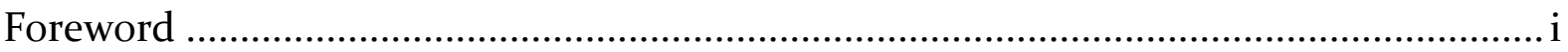

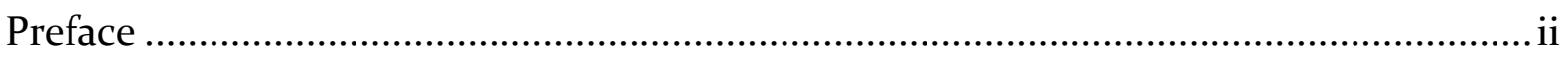

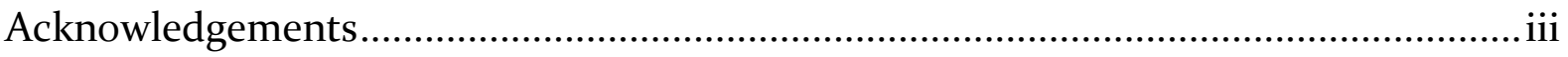

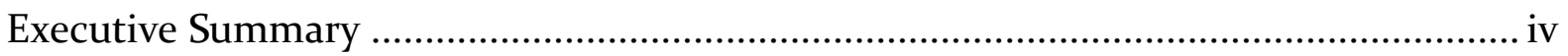

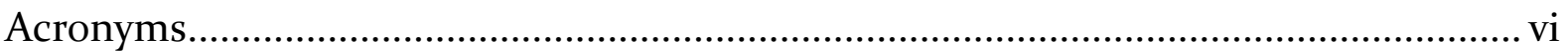

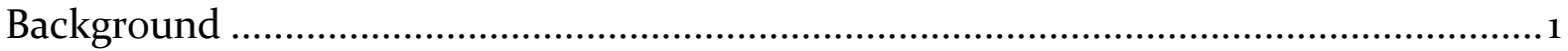

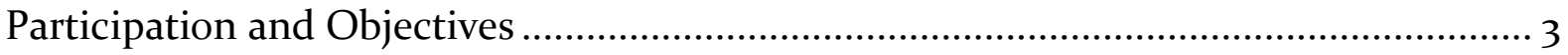

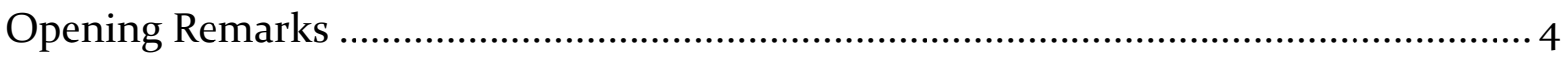



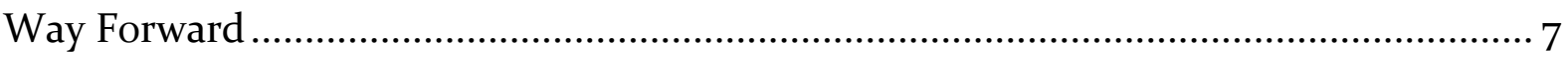

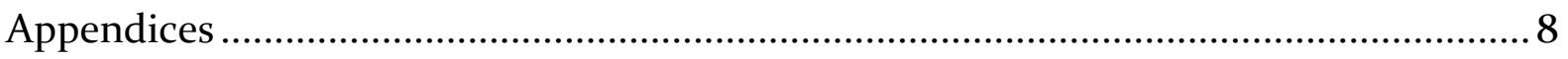

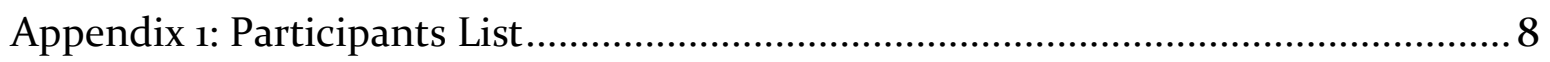

Appendix 2: Meeting Agenda ......................................................................... 13

Appendix 3: List of Presentations ................................................................... 15 


\section{Acronyms}

$\begin{array}{ll}\text { AIDS } & \text { Acquired Immune Deficiency Syndrome } \\ \text { CSA } & \text { Child Sexual Abuse } \\ \text { EC } & \text { Emergency Contraception } \\ \text { ECSA } & \text { East, Central and Southern Africa } \\ \text { GBV } & \text { Gender-Based Violence } \\ \text { HIV } & \text { Human Immuno-Deficiency Virus } \\ \text { PEP } & \text { Post-Exposure Prophylaxis for HIV } \\ \text { RIA } & \text { Research, Information and Advocacy (Programme) } \\ \text { STI } & \text { Sexually Transmitted Infection }\end{array}$




\section{Background}

The East, Central and Southern Africa Health Community (ECSA Health Community) is a regional, inter-governmental health organization that fosters and promotes regional cooperation around common health challenges facing the region, and strengthens regional capacity to address the health needs of Member States. A principal priority is to promote the efficiency and effectiveness of health services through collaboration, research, capacity-building, policy development, and advocacy. Member States of ECSA Health Community include Kenya, Lesotho, Malawi, Mauritius, Seychelles, Swaziland, United Republic of Tanzania, Uganda, Zambia and Zimbabwe.

ECSA Health Community is governed through several main organs, including the ECSA Conference of Health Ministers - the ECSA Health Community's highest governing body which meets annually to define regional health priorities, and review policy matters and national health strategies.

Since 2006, ECSA Health Community has prioritized gender-based violence (GBV) and child sexual abuse (CSA) as regional health issues, and has provided guidance to its Member States in addressing these challenges. In 2006, the $42^{\text {nd }}$ Conference of Health Ministers called for the review and establishment of mechanisms to address GBV and CSA in the region, and in 2010, the Conference passed a landmark resolution (Resolution ECSA/HMC 52/R4) which urged Member States to 1) adopt/adapt the ECSA Health Community Regional Prototype Policy on GBV and CSA, and 2) establish or strengthen a national Gender Commission to oversee GBV- and CSA-related interventions, including coordination, advocacy, and establishment of monitoring and evaluation (M\&E) systems.

Programme Expert Committees also form a key part of ECSA Health Community's governance bodies. These are technical committees that draw on expertise from Member States' programme managers, external advisors, professional associates, and consultants from the region. From December 11-12, 2012, the Research, Information and Advocacy (RIA) Programme of ECSA Health Community partnered with the Population Council (Nairobi, Kenya) to convene an RIA Programme Expert Committee Meeting entitled 'Scaling Up Advocacy for GBV and CSA in the ECSA Region.'

The Population Council has provided technical assistance and conducted research to strengthen the evidence base on GBV and CSA programming in the ECSA region. These activities have created an active network of partners from across the region (known as the 'Africa Regional Sexual and Gender-Based Violence Network' [http://www.svri.org/popcouncil.htm]) that are developing, implementing and evaluating core elements of a comprehensive, multi-sectoral response model (see Figure 1). The East, Central and Southern Africa Health Community is a partner in this Network. The model embraced by the Network incorporates the overlapping and complementary responsibilities of three core sectors: health, police and justice, and social service sectors. It also recognizes that survivors require access to all services, but that it may not be feasible, appropriate or cost-effective to deliver all services in one location. 


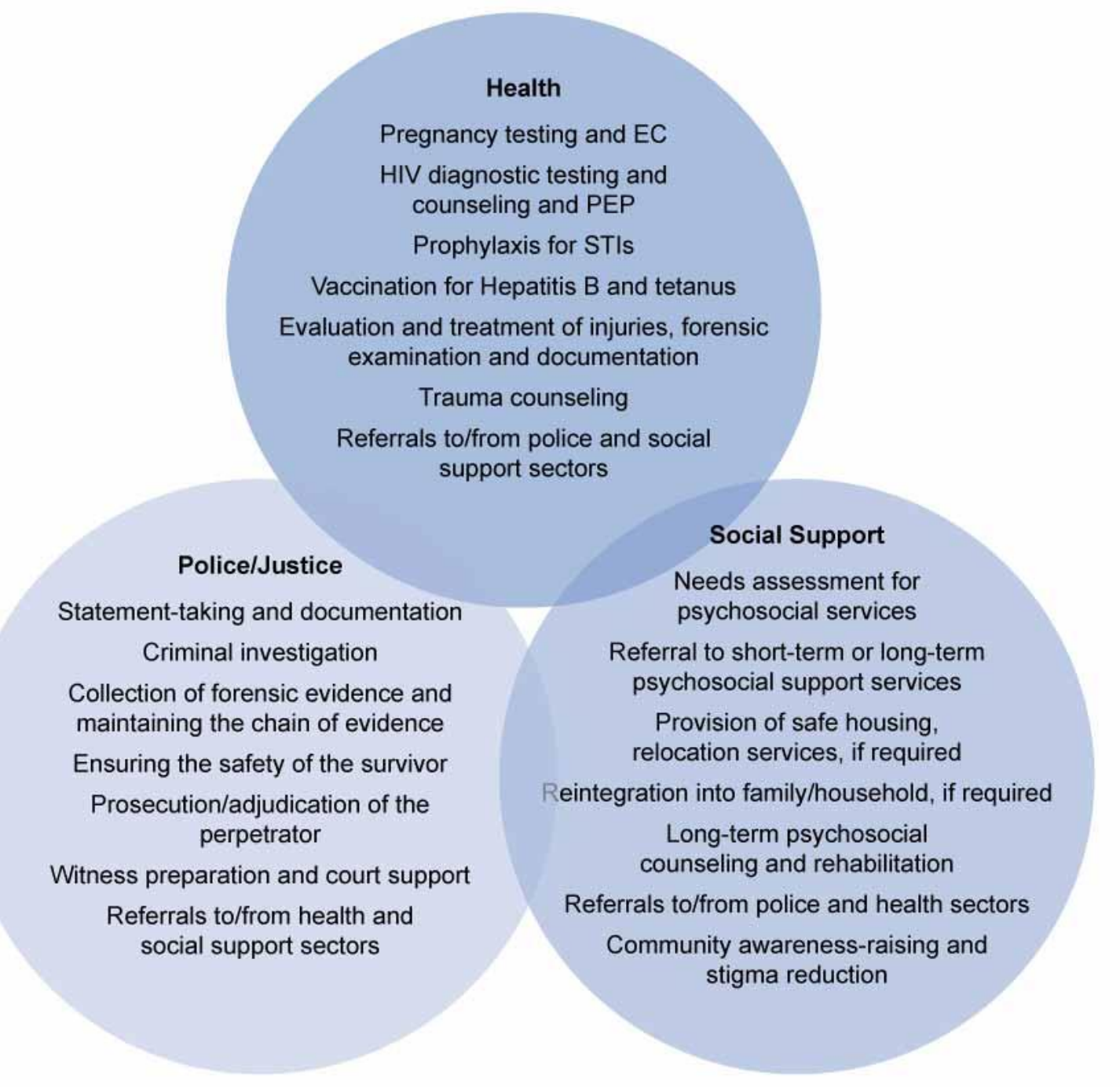

Lessons learned from this regional Network served as a resource for meeting participants, advancing understanding of GBV in the ECSA region, identifying effective program strategies and gaps in response efforts, and inspiring advocacy efforts around such strategies.

To foster this sort of exchange among participants, and to institutionalize advocacy action around these issues, ECSA Health Community, with funding from the SwedishNorwegian Regional HIV and AIDS Team for Africa (through the Population Council), convened this pre-conference meeting in Arusha, Tanzania. This report details the meeting proceedings. 


\section{Participation and Objectives}

Over thirty participants attended the two-day pre-conference meeting, which fed into the $5^{\text {th }}$ ECSA Health Ministers Conference. Participants at the pre-conference meeting represented Gender Focal Points and Public Relations Officers (both drawn from Ministries of Health), journalists, and development partners from Kenya, Lesotho, Malawi, Mauritius, Tanzania, Uganda, Zambia, and Zimbabwe (see Appendix 1 for a participants list).

Three main objectives guided the Research, Information and Advocacy Expert Committee pre-conference meeting of the ECSA Health Community:

- Share emerging lessons from the region on 'doable' GBV interventions and advocacy activities

- Identify and prioritize regional advocacy concerns

- Draw country-specific advocacy plans to feed into a comprehensive, regional plan

- Define media involvement in implementing the advocacy plans and in propelling the agenda forward

- Define mechanisms for accelerating advocacy through the RIA Expert Committee

The meeting provided an opportunity for Member States to share experiences, learn from one another, derive inspiration for advocacy activities around GBV and CSA, and create linkages for their work. For the journalists in attendance, this was also a forum for developing original stories around GBV to be disseminated in their countries (the Media Network Gallery page for this meeting is available here: http://www.ecsahc.org/downloads/GBV\%2ostories.docx).

The meeting was structured around plenary sessions, including presentations and discussion. Group discussions, the mapping of the way forward for the establishment of the ECSA Health Community's RIA Program's Expert Committee, and for the establishment of mechanisms for accelerated advocacy around GBV in the region, also defined the meeting structure (see Appendix 2 for the agenda).

Each session stimulated active discussion and recommendations for advocacy on key GBV issues. All presentations are available on the ECSA Health Community website: http://www.ecsahc.org/doc listing.php?CategoryID=43.

Highlighted in the remainder of this report are the key themes, discussion points and conclusions of the meeting. 


\section{Opening Remarks}

Meeting participants were honored to have the conference declared officially open by Dr. Josephine Kibaru-Mbae, the Director-General of ECSA Health Community. Dr. Kibaru-Mbae warmly welcomed participants, reminding them that the meeting had a special focus on GBV, and highlighting the fact that GBV is a human rights violation with social, health, and economic impacts. Providing an overview of GBV issues in the region, Dr. Kibaru-Mbae stressed the importance of raising public awareness around the issue, and of the media's role in this endeavor, coupled with country-level advocacy plans. Pointing out that the meeting would lead to the formation of the very first Expert Committee of ECSA Health Community's Research, Information and Advocacy Programme, Dr. Kibaru-Mbae urged participants to demonstrate their commitment by supporting and providing technical assistance to the RIA Programme as necessary in order for ECSA Health Community to more effectively respond to the demands of its mandate in health advocacy and knowledge and information sharing in the region.

ECSA Health Community's Director-General was joined by the Permanent Secretary, Ministry of Health and Quality of Life, Mauritius, Mr. Omaduth Jadoo; Dr. Odongo Odiyo, ECSA Health Community's Manager, Family and Reproductive Health; and Dr. Chi-Chi Undie of the Population Council in providing opening remarks. Mr. Omaduth Jadoo congratulated Ministries of Health in the region for taking the lead in the areas of GBV and CSA by developing policies and strategies. He encouraged Member States, however, to each look toward having national frameworks in order to effectively respond to the regional calamity of violence.

Dr. Odiyo reiterated the need to identify appropriate advocacy responses to the multisectoral issue of GBV. Pointing out that ECSA Health Community's RIA Programme was the most logical entry-point for moving GBV work forward in the region, Dr. ChiChi Undie expressed excitement about the possibility of moving beyond pilots to advocacy for going to scale with GBV responses that have been tested and proven effective.

\section{Summary of Discussions}

Presentations covered an overview of the regional GBV and CSA situation, as well as related advocacy issues. These were complemented by presentations from Member States on the status of GBV and CSA in their individual countries, along with the status of countries' implementation of the ECSA ministerial resolutions around GBV. Key issues that emerged from the discussion are elaborated upon below.

\section{i. Associations between GBV and other health issues/disease burdens need to be clarified.}

Although GBV is an important driver in the HIV epidemic in the region, and has adverse consequences for survivors' physical, mental, and reproductive health, deliberations at the meeting revealed that GBV as a contributor to the regional disease burden (and, therefore, as a major public health issue) requires further publicisation. 
As part of this effort, greater synergies are also needed between various Ministries. For instance, although the Ministry of Health typically provides GBV services at facility level among Member States, the task of advocacy and resource mobilization for GBV may fall under another Ministry's docket (e.g., Ministry of Gender). More traction is likely to be gained from Ministries working more closely together on the issue of GBV.

\section{ii. Inter-ministerial coordination in national GBV responses requires strengthening.}

Seeing it as key to fostering a multi-sectoral approach to GBV in ECSA countries, participants stressed the need for other Ministries (e.g., Ministries of Gender) to be brought on board to work closely with ECSA Health Community's Health Ministers on the response to GBV. Participants learned that the ECSA Health Community does engage with other Ministries beyond Ministries of Health (including Ministries of Gender, Ministries of Finance, for example); however, these linkages between Ministries can be strengthened further in order to ensure that the needs of GBV survivors (see Figure 1 above) are more effectively addressed in the region.

Related to this issue was the question of which Ministry was best-placed to take the lead on the GBV response in Member States. The consensus was that the Ministry leading this effort in each country need not be set in stone as each country is unique. Ensuring that collaboration is occurring between relevant Ministries on responding to GBV was considered as being most essential.

\section{iii. Knowledge about the status of child sexual abuse is still sparse in the region.}

Data presented by the Population Council demonstrated that children constitute a significant proportion of those seeking GBV services. An ECSA Health Community report entitled Child Sexual Abuse in sub-Saharan Africa: A Review of the Literature, distributed at the meeting, also emphasized the magnitude of the CSA problem in the region. Information on CSA was largely absent from presentations by Member States, however, signaling a lack of knowledge on the status of CSA within the region and a need for further research and programming in this area. Participants also noted that although the ECSA Health Community Guidelines for the Clinical Management of Child Sexual Abuse exist and are currently being adopted or adapted by ECSA Member States, few providers in the region have the professional preparation required to appropriately and effectively tend to the needs of child survivors.

\section{iv. In-service training for providers should incorporate a specific focus on GBV.}

Many GBV activities in the region have involved the strengthening of response services, primarily though the development of linkages between the health, social, and legal sectors. Participants, however, recognized that the in-service training of providers has been overlooked. Rationalizing that such training would ensure GBV programming is seen as part of providers' responsibilities, rather than part of a new, temporary initiative, participants stressed the importance of in-service training for an effective multi-sectoral approach. 


\section{v. Similar priorities areas for GBV advocacy were identified by individual Member States.}

Representatives from Member States across the region identified remarkably similar priorities for advocacy around GBV in their respective countries:

- advocacy for resource allocation for GBV and CSA by governments and/or resource mobilization through donor engagement (prioritized by 6 out of the 8 Member States in attendance);

- advocacy to address social norms that promote GBV and CSA in order to prevent violence in the first place;

- advocacy to work with the media in order to raise the profile of GBV and CSA;

- advocacy to build the capacity of providers (including health care workers, police, etc.) to respond to GBV and CSA.

Other areas for advocacy which were mentioned less frequently, but which are of importance include advocacy for increased coordination and collaboration between GBV stakeholders; the need to translate existing, in-country GBV instruments into action; advocacy for perpetrator rehabilitation, ${ }^{1}$ and advocacy for attention to the issue of violence against men, for example.

One session during the meeting involved the presentation of a testimony by a GBV survivor from the ECSA region. The presentation inspired animated discussion and questioning, leaving the journalist participants in particular with a conviction that advocating for a multi-sectoral response to GBV via the media is essential.

\section{vi. Despite the limitations that exist in many countries, multi-sectoral GBV interventions are doable.}

The survivor's testimony mentioned above underscored the need for a multi-sectoral response to GBV. Results from the Africa Regional GBV Network (http://www.svri.org/popcouncil.htm), coordinated by the Population Council, were presented at the meeting, highlighting the fact that various multi-sectoral models of care have been explored and documented in the region (Kenya, Malawi, South Africa, Swaziland, Zambia), and are feasible and effective, with potential for scale-up in the region.

\section{vii. ECSA Health Community's Research, Information and Advocacy Expert Committee was formally established.}

A major outcome of the two-day meeting was the development of the terms of reference for the establishment of ECSA Health Community's Research, Information

\footnotetext{
${ }^{1}$ Mauritius currently has an initiative that seeks to address this issue, the rationale being that convicted perpetrators are likely to turn pariahs and commit similar acts if not properly reintegrated
} 
and Advocacy Expert Committee. Each ECSA Health Community program ${ }^{2}$ is typically guided by an individual Expert Committee, but ECSA Health Community's Research, Information and Advocacy program had not established such a mechanism prior to this two-day pre-conference meeting. ECSA Health Community's newest Expert Committee on Research, Information and Advocacy was later ratified by the $56^{\text {th }}$ Health Ministers Conference (December 13-14, 2012), formally establishing the RIA Expert Committee as the fifth such committee of ECSA Health Community.

The RIA Expert Committee is uniquely positioned to facilitate and support regionwide sharing and utilization of health-related research and policy information among Member States and to use research from other ECSA Health Community programmes to support evidence-informed advocacy for health rights.

Meeting participants (who formed the membership of the RIA Expert Committee) committed to prioritize gender-based violence and child sexual abuse in their work. Expert Committee members also agreed to establish an ECSA Health Community Award for Media Excellence to encourage, recognize and support media practitioners to document, analyze, report and disseminate health-related issues (including GBV) in the region.

\section{Way Forward}

ECSA countries represented at the meeting committed to submitting detailed, country-specific action plans by January 30, 2013. The final version of these action plans will be submitted to ECSA Health Community Health Ministers for their approval. Following this, ECSA Health Community, in collaboration with various partners, will provide technical and financial support to select member countries for implementation in 2013.

\footnotetext{
${ }^{2}$ ECSA Health Community's current programs include: Food Security and Nutrition; Family and Reproductive Health; Health Systems and Services Development; Human Resources for Health; HIV/AIDS and Infectious Diseases; Monitoring and Evaluation; and Research, Information and Advocacy.
} 


\section{Appendices}

\section{Appendix 1: Participants List}

\begin{tabular}{|c|c|}
\hline Country & Name and Contact Information \\
\hline KENYA & $\begin{array}{l}\text { Mr. John Kinuthia } \\
\text { Head, PR and Public Communications, Ministry of Public Health and Sanitation } \\
\text { P.O. Box } 4331900100 \\
\text { Nairobi, Kenya } \\
\text { Tel: +254 } 2027893 \\
\text { Fax: + } 254733862031 \\
\text { Email:ibgkinuthia@yahoo.com }\end{array}$ \\
\hline KENYA & $\begin{array}{l}\text { Dr. Pamela Godia } \\
\text { Program Manager, Ministry of Public Health and Sanitation } \\
\text { P.O. Box } 9990057 \\
\text { Nairobi, Kenya } \\
\text { Tel: +254 } 722659282 \\
\text { Email: godiapam@yahoo.com }\end{array}$ \\
\hline LESOTHO & $\begin{array}{l}\text { Ms. Mateboho Mosebekoa } \\
\text { Public Relations Officer, Ministry of Health } \\
\text { P.O Box } 514 \\
\text { Maseru, lesotho } \\
\text { Tel +266 } 22324955 \\
\text { Cell: +266 } 63029763 \\
\text { Email: matebohom6@gmail.com }\end{array}$ \\
\hline LESOTHO & $\begin{array}{l}\text { Ms Joyce Nkone Mohaeka } \\
\text { News Reporter, Day Flyer Newspapers } \\
\text { P.O. Box } 1134 \\
\text { Maseru, Lesotho } \\
\text { Tel: + } 26622322002 \\
\text { Cell: + } 26662080006 \\
\text { nmohaeka@yahoo.com }\end{array}$ \\
\hline MALAWI & $\begin{array}{l}\text { Henry Chimbali } \\
\text { Head of Public Relations, Ministry of Health } \\
\text { P.O. Box } 30377 \\
\text { Lilongwe, Malawi } \\
\text { Tel: +265 } 5175899 \\
\text { Cell: +265 } 999890047 \\
\text { Email: chimbalih@yahoo.com }\end{array}$ \\
\hline MALAWI & $\begin{array}{l}\text { Mrs Hellen Milonde } \\
\text { Nurse, Secretary Sexually Transmitted \& Infection } \\
\text { Coordinator/GBV Focal Person, Ministry of Health ( Kamuzu Central Hospital) } \\
\text { P.O. Box 149, Lilongwe, Malawi } \\
\text { Tel: +265 } 1751480 \\
\text { Tel: + } 265999303734 \\
\text { Email: helenmilonde@yahoo.com }\end{array}$ \\
\hline
\end{tabular}




\begin{tabular}{|c|c|}
\hline Country & Name and Contact Information \\
\hline & $\begin{array}{l}\text { Mr. Innocent Chitosi } \\
\text { Editor, Malawi News } \\
\text { Private bag, } 39 \\
\text { Blantyre, Malawi } \\
\text { Tel: + } 265111621343 \\
\text { Cell: + } 265888861096 \\
\text { Email: i_chitosi@rocketmail.com }\end{array}$ \\
\hline MAURITIUS & $\begin{array}{l}\text { Mr. Harish Fhooblall } \\
\text { Advisor on Information Matters, Government of Mauritius } \\
\text { Ministry of Health and Quality of Life } \\
\text { 5th Floor, Emmanuel Anquetil Building, Port Lois, Mauritius } \\
\text { Tel: +230 } 2011512 \\
\text { Fax: + } 2302016911 \\
\text { Email: harishfhooblall@gmail.com } \\
\text { hfhooblall@mail.gov.mu }\end{array}$ \\
\hline MAURITIUS & $\begin{array}{l}\text { Mr. Bedassur Rajkumar Nandansigh } \\
\text { Information Officer, Ministry of Health and Quality of Life } \\
\text { 5th Floor, Emanuel Anquetil Building } \\
\text { Port Louis, MAURITIUS } \\
\text { Tel: + } 2302012884 \\
\text { Fax: + } 2302016093 \\
\text { Email: navinbebassur@yahoo.com }\end{array}$ \\
\hline MAURITIUS & $\begin{array}{l}\text { Mr. Omaduth Jadoo } \\
\text { Permanent Secretary, Ministry of Health and Quality of Life } \\
\text { 5th Floor, Emanuel Anquetil Building } \\
\text { Port Louis, MAURITIUS } \\
\text { Tel:+230 } 2011902 \\
\text { Cell: + } 2302553056 \\
\text { Email: ojadoo@mail.mu }\end{array}$ \\
\hline TANZANIA & $\begin{array}{l}\text { Mr. Nsachris Mwawaja } \\
\text { Communication Officer, Ministry of Health and Social Welfare } \\
\text { P.O. Box } 9083 \\
\text { Dar Es Salaam, Tanzania } \\
\text { Cell: + } 255754272574 \\
\text { Email: nsachrism@yahoo.co.uk }\end{array}$ \\
\hline TANZANIA & $\begin{array}{l}\text { Mr Masembe Tambwe } \\
\text { Journalist, Daily News } \\
\text { P.O. Box } 9033 \\
\text { Dar Es Salaam, Tanzania } \\
\text { Email: mtambwe@dailynews-tsn.com }\end{array}$ \\
\hline TANZANIA & $\begin{array}{l}\text { Geoffrey Stephen Paulo } \\
\text { Radio } 5 \\
\text { P.O Box } \\
\text { Arusha, Tanzania } \\
\text { Tel+ } 255755984225 \\
\text { Email: geocarpten@gmail.com }\end{array}$ \\
\hline
\end{tabular}




\begin{tabular}{|c|c|}
\hline Country & Name and Contact Information \\
\hline TANZANIA & $\begin{array}{l}\text { Victoria Kuvuna Mwakoyo } \\
\text { Creative Manager, Radio Manager } \\
\text { P.O. Box } 11843 \\
\text { Arusha, Tanzania } \\
\text { Tel: + } 255759239105 \\
\text { Email: vicky@tanmedia.co.tz }\end{array}$ \\
\hline UGANDA & $\begin{array}{l}\text { M. Rukia Nakamatte } \\
\text { Public Relations Officer, Ministry of Health } \\
\text { P.O. Box } 7272 \\
\text { Kampala, Uganda } \\
\text { Tel: +256 774-063 } 888 \\
\text { Cell+256 } 41231582 \\
\text { Email: mbrukia@yahoo.co.uk }\end{array}$ \\
\hline UGANDA & $\begin{array}{l}\text { Ms. Florence Naluyimba } \\
\text { Journalist Science and Health Reporter, NTV Uganda } \\
\text { P.O. Box } 35933 \\
\text { Kampala, Uganda } \\
\text { Tel: } 256414563400 \\
\text { cell: +256 } 782036723 \\
\text { Email: f.mujaasi@gmail.com }\end{array}$ \\
\hline UGANDA & $\begin{array}{l}\text { Ms. Miriam Namugeere } \\
\text { Principal Nursing Officer, Ministry of Health } \\
\text { P.O. Box } 7272 \\
\text { Kampala, Uganda } \\
\text { Tel: +256 } 41340874 \\
\text { Cell: + } 256772474184 \\
\text { Fax: + } 25604231584 \\
\text { Email: nmigeere@yahoo.co.uk }\end{array}$ \\
\hline ZAMBIA & $\begin{array}{l}\text { Dr Tasila Mercy Tembo } \\
\text { Deputy Director in Charge of Health Education, Ministry of Health } \\
\text { P.O.Box } 30205 \\
\text { Lusaka, Zambia } \\
\text { Tel: + } 260211258509 \\
\text { Cell: + } 26097945009 \\
\text { Email: tpitters@moh.gov }\end{array}$ \\
\hline ZAMBIA & $\begin{array}{l}\text { Ms Faith Kandaba } \\
\text { Senior Health Journalist, Zambia National Broadcasting Corporation } \\
\text { P.O. Box } 5005 \\
\text { Lusaka, Zambia } \\
\text { Tel: +260 } 2125983 \\
\text { Cell: + } 260977772024 \\
\text { Fax: + } 26021253141 \\
\text { Email: faithkandaba@yahoo.com }\end{array}$ \\
\hline ZIMBABWE & $\begin{array}{l}\text { Mr. Mujiri Donald } \\
\text { National Public Relations Manager, Ministry of Health and Child Welfare } \\
\text { P.O. Box CY } 1122 \\
\text { Causeway, Harare } \\
\text { Zimbabwe } \\
\text { Cell No: +263 } 712867337 \\
\text { Fax No+263 } 4702368 \\
\text { E-mail: dmujiri@gmail.com }\end{array}$ \\
\hline
\end{tabular}




\begin{tabular}{|l|l|}
\hline Country & Name and Contact Information \\
\hline ZIMBABWE & Ms. Paidamoyo Clover Chipunza \\
& Senior Health Reporter/Journalist, Zimpapaers-The Herald Newspapers \\
& P.O. Box 396 Causeway Harare Zimbabwe \\
& Tel No: +263772599 752 \\
& Cell No: +263 772599752 \\
& E-mail: paidamoyo.chipunza@zimpapers.co.zW \\
\hline ZIMBABWE & Mrs Fatima Mhuriro \\
& SRH \& HIV Linkages Programme Coordinator, Ministry of Health and Child Health \\
& Kaguvi Building Central/ Avenue/4th Street \\
& Harare, Zimbabwe \\
& Tel: +263 4 4798529 \\
& Cell: + 263 772 236 026 \\
& Email: fmhuriro@yahoo.co.uk \\
\hline
\end{tabular}

\begin{tabular}{|l|l|}
\hline Organization & Name and Contact information \\
\hline AFRICA HEALTH & Travor Mabugu \\
ECONOMICS AND & Africa Economics and Policy Association \\
POLICY & Zimbabwe \\
ASSOCIATION & Tel: +263 777 280301 \\
& Email: travormabugu@yahoo.com \\
\hline ECSA HEALTH & Dr. Odongo Odiyo \\
COMMUNITY & Manager, Family and Reproductive Health \\
& ECSA Health Community \\
& P.O. Box 1009 \\
& Arusha, Tanzania \\
& Tel: + 255 27 254 9362 \\
& Mob: + 255 759 335 797 \\
& Email: odongo@ecsa.or.tz \\
\hline ECSA HEALTH & Mr. Arthur Rutaroh \\
COMMUNITY & Manager, Research, Information and Advocacy \\
& ECSA Health Community \\
& P.O. Box 1009 \\
& Arusha, Tanzania \\
& Tel: + 255 27 254 9362 \\
& Mob: + 255 687 179 449 \\
& Email: arutaroh@ecsa.or.tz \\
\hline ECSA HEALTH & Mr. Sibusiso Sibandze \\
COMMUNITY & Manager, Monitoring \& Evaluation \\
& ECSA H ECSA Health Community \\
& P.O. Box 1009 \\
& Arusha, Tanzania \\
& Tel: + 255 27 254 9362 \\
& Mob: + 255 688 514 026 \\
& Email: s_sibandze@ecsa.or.tz \\
\hline
\end{tabular}




\begin{tabular}{|c|c|}
\hline Organization & Name and Contact information \\
\hline $\begin{array}{l}\text { ECSA HEALTH } \\
\text { COMMUNITY }\end{array}$ & $\begin{array}{l}\text { Mr. Adam Msilaji } \\
\text { Information Communication and Documentation Officer } \\
\text { ECSA Health Community } \\
\text { P.O. Box } 1009 \\
\text { Arusha, Tanzania } \\
\text { Tel: + } 255272549362 \\
\text { Mob: + } 255754465467 \\
\text { Email: amsilaji@ecsa.or.tz }\end{array}$ \\
\hline $\begin{array}{l}\text { ECSA HEALTH } \\
\text { COMMUNITY }\end{array}$ & $\begin{array}{l}\text { Ms. Doreen Marandu } \\
\text { Programme Officer } \\
\text { ECSA Health Community } \\
\text { P.O. Box } 1009 \\
\text { Arusha, Tanzania } \\
\text { Tel: + } 255272549362 \\
\text { Mob: + } 255754369954 \\
\text { Email: dmarandu@ecsa.or.tz }\end{array}$ \\
\hline $\begin{array}{l}\text { ECSA HEALTH } \\
\text { COMMUNITY }\end{array}$ & $\begin{array}{l}\text { Ms. Christine Mhanusi } \\
\text { Resource Center Assistant } \\
\text { ECSA Health Community } \\
\text { P.O. Box } 1009 \\
\text { Arusha, Tanzania } \\
\text { Tel: + } 255272549362 \\
\text { Mob: + } 255754594313 \\
\text { Email: frhp@ecsa.or.tz }\end{array}$ \\
\hline $\begin{array}{l}\text { KENYATTA } \\
\text { NATIONAL } \\
\text { HOSPITAL }\end{array}$ & $\begin{array}{l}\text { Linda Munyendo } \\
\text { Peer Mentor } \\
\text { Kenyatta National Hospital } \\
\text { P.O. Box 3118-0100 } \\
\text { Nairobi, Kenya } \\
\text { Mob: +254 } 725317864 \\
\text { Email: imunyendo@gmail.com }\end{array}$ \\
\hline $\begin{array}{l}\text { POPULATION } \\
\text { COUNCIL }\end{array}$ & $\begin{array}{l}\text { Dr. Chi-Chi Undie } \\
\text { Associate } \\
\text { Population Council } \\
\text { P.O. Box 17643-00500 } \\
\text { Nairobi, Kenya } \\
\text { Tel: +254 } 20273480 \\
\text { Mob: +254 } 697784 \\
\text { Email: cundie@popcouncil.org }\end{array}$ \\
\hline $\begin{array}{l}\text { POPULATION } \\
\text { COUNCIL }\end{array}$ & $\begin{array}{l}\text { Mr. Justus Olielo } \\
\text { Research Uptake Manager } \\
\text { Population Council } \\
\text { P.O. Box 764-00500 } \\
\text { Nairobi, Kenya } \\
\text { Tel: +254 } 20273480 \\
\text { Cell: + } 254722823436 \\
\text { Email: jolielo@popcouncil.org }\end{array}$ \\
\hline
\end{tabular}




\section{Appendix 2: Meeting Agenda}

'Scaling Up Advocacy for GBV and CSA in the ECSA Region'

\section{Expert Committee Meeting of the Research, Information and Advocacy Program East, Central and Southern Africa Health Community \\ 11-12 December, 2012}

Ngurdoto Mountain Lodge Hotel, Arusha, Tanzania

\begin{tabular}{|c|c|c|}
\hline \multicolumn{3}{|c|}{$\begin{array}{l}\text { Master of Programmes : Mr. Rutaroh Arthur - ECSA } \\
\text { Rapporteurs: Mr. Adam \& Ms. Doreen - ECSA }\end{array}$} \\
\hline TIME & TOPICS/ACTIVITIES & Responsible \\
\hline $08.00-08.30$ & $\begin{array}{l}\text { Registration and Distribution of Documents } \\
\text { Administrative Formalities }\end{array}$ & ECSA team \\
\hline \multirow[t]{2}{*}{$0830-10: 00$} & \multicolumn{2}{|c|}{$\begin{array}{l}\text { - Introductions - All } \\
\text { - Welcome Remarks by Arthur Rutaroh (ECSA MRIA) } \\
\text { - Remarks by Dr. Odongo Odiyo (ECSA MFRH) } \\
\text { - Remarks by Dr. Chi-Chi Undie (Associate, Population Council) } \\
\text { - Official Opening by Dr. Josephine Kibaru-Mbae (DG ECSA) }\end{array}$} \\
\hline & $\begin{array}{l}\text { Expectation and Objectives } \\
\text { Introduction of ECSA Programmes }\end{array}$ & Arthur Rutaroh \\
\hline $10.00-10.30$ & Group photo \& HEALTH BREAK & \\
\hline $10: 30-11: 00$ & Overview of GBV \& CSA situation in the region & Dr. Odongo \\
\hline $11.00-11.45$ & $\begin{array}{l}\text { Interventions and tools to respond to GBV \& CSA: } \\
\text { Evidence and practice }\end{array}$ & Dr. Chi-Chi Undie \\
\hline $11.45-13.00$ & $\begin{array}{l}\text { Country presentations on the status of GBV and CSA } \\
\text { and the implementation of the ECSA ministerial } \\
\text { resolutions } \\
\text { \& Discussion }\end{array}$ & All Member States \\
\hline $13: 00-14: 00$ & Lunch & \\
\hline $14: 00-14: 30$ & $\begin{array}{l}\text { Problem analysis and the need to scale up advocacy in } \\
\text { the implementation of the regional and country tools in } \\
\text { the MS }\end{array}$ & $\begin{array}{l}\text { Dr. Odongo Odiyo } \\
\text { Dr. Chi-Chi Undie, Justus Olielo }\end{array}$ \\
\hline $14.30-15: 30$ & Discussion & All \\
\hline $15.30-16.00$ & $\begin{array}{l}\text { Recommendations on the implementation of the policy } \\
\text { and guidelines }\end{array}$ & $\begin{array}{l}\text { Dr. Odongo Odiyo } \\
\text { Dr. Chi-Chi Undie }\end{array}$ \\
\hline
\end{tabular}




\begin{tabular}{|l|l|l|}
\hline $16.00-16.15$ & $\begin{array}{l}\text { Introduction to the Development of country advocacy } \\
\text { plans }\end{array}$ & $\begin{array}{l}\text { Arthur Rutaroh } \\
\text { Justus Olielo }\end{array}$ \\
\hline $16.15-17.00$ & Development of country advocacy plans & Country teams \\
\hline $17: 00-17: 30$ & Health Break \& end of day one & All \\
\hline
\end{tabular}

\begin{tabular}{|c|c|c|}
\hline \multicolumn{3}{|c|}{ DAY 2: Wednesday 12 December, 2012} \\
\hline Time & Topics /Activities & Chair: \\
\hline $08.00-09.00$ & - Presentation of the highlights of country plans & All \\
\hline $0900-09.30$ & $\begin{array}{l}\text { - Presentation of the ECSA plans to support countries on } \\
\text { GBVICSA }\end{array}$ & Dr. Odongo Odiyo \\
\hline $09.30-10.00$ & Conclusion and way forward & Arthur Rutaroh \\
\hline $10.00-10.30$ & HEALTH BREAK & \\
\hline $10.30-10.45$ & $\begin{array}{l}\text { RIA Expert meeting } \\
\text {-Election of the Chair Person } \\
\text {-RIA Programme Overview } \\
\text {-RIA mandate } \\
\text {-ECSA Strategic Focus }\end{array}$ & Chair. RIA Expert Meeting \\
\hline $10.45-13.00$ & $\begin{array}{l}\text { Review of Documents } \\
\text {-Award for excellency strategy } \\
\text {-Advocacy, Communication, and Documentation Strategy }\end{array}$ & Chair. RIA Expert Meeting \\
\hline $13: 00-14: 00$ & Lunch & \\
\hline $14: 00-16: 30$ & Developing new Strategy in priority areas & Chair. RIA Expert Meeting \\
\hline $16: 30-17: 00$ & $\begin{array}{l}\text { Introduction to Health Ministers Conference (HMC) Coverage of } \\
\text { HMC Deliberations and way forward }\end{array}$ & ECSA \\
\hline
\end{tabular}




\section{Appendix 3: List of Presentations}

(All presentations are available here:

http://www.ecsahc.org/doc listing.php?CategoryID=43)

Presentation 1: Arthur Rutaroh. Scaling up advocacy for Gender-Based Violence and Child Sexual Abuse in ECSA Health Community Region: Meeting expectations and Objectives.

Presentation 2: Arthur Rutaroh. The ECSA Health Community Governing Structure.

Presentation 3: Dr. Odongo Odiyo. Overview of the GBV and CSA Situation in the ECSA Region.

Presentation 4: Dr. Pamela Godia. GBV/CSA Situation in Kenya.

Presentation 5: Mateboho Mosebekoa. GBV/CSA Situation in Lesotho.

Presentation 6: Hellen Milonde. GBV/CSA Situation in Malawi.

Presentation 7: Omaduth Jadoo. GBV/CSA Situation in Mauritius.

Presentation 8: Miriam Namugeere. GBV/CSA Situation in Uganda.

Presentation 9: Faith Kandaba. GBV/CSA Situation in Zambia.

Presentation 1o: Fatima Mhuriro. GBV/CSA Situation in Zimbabwe.

Presentation 11: Dr. Chi-Chi Undie. Interventions and Tools to Respond to GBV and CSA: Evidence and Practice.

Presentation 12: Dr. Chi-Chi Undie. Demystifying Advocacy: Lessons from the ECSA Region.

Presentation 13: Kenya GBV Advocacy Issues.

Presentation 14: Lesotho GBV Advocacy Issues.

Presentation 15: Malawi GBV Advocacy Issues.

Presentation 16: Mauritius GBV Advocacy Issues.

Presentation 17: Tanzania GBV Advocacy Issues.

Presentation 18: Uganda GBV Advocacy Issues.

Presentation 19: Zambia GBV Advocacy Issues.

Presentation 2o: Zimbabwe GBV Advocacy Issues. 